\title{
Organization of Documentation in Ukraine during the Soviet Period
}

\author{
Vira Gamaliia \\ State University of Infrastructure and Technology \\ Kyrylivska 9 \\ Kyiv 02000, Ukraine \\ Email:vgamaliia@gmail.com
}

\section{Igor Dovzhuk}

Hryhorii Skovoroda University in Pereiaslav

Sukhomlynsky 30

Pereiaslav, Kyivregion 08401, Ukraine

Email: i.v.dovzhuk@ukr.net

\section{Halyna Sichkarenko}

State University of Telecommunications

Solomenska 7

Kyiv 03680, Ukraine

Email: gsich54@dmail.com

\begin{abstract}
The article discusses issues surrounding the introduction of new forms of documents and the organization of document circulation in Ukraine during the Soviet period, revises the organization of office work and presents a selection of valuable documents. The authors also explore the organizational and scientific activities in the field of management, stipulated in regulatory enactments, and describe the creation of a network of public organizations, institutes and laboratories that dealt with issues of scientific organization of labor and reference activities. In the article, an analysis of the organization of office work and archival management through the evolution of regulatory framework is presented, highlighting the most important stages of the organization of documentation in the USSR. It is noted that, by the end of the 1980s, a holistic system of documentation support, which met at that time the requirements of Soviet business broadcasting and the standards of compiling official documents, had been formed.
\end{abstract}


Vira Gamaliia

Igor Dovzhuk

Halyna Sichkarenko

Keywords: documentation science, labor organization, normative base, office work, scientific organization of labor

\section{Introduction}

Documentation is the process of creating a document which is provided by the public authorities responsible for the organization of office work and standardization of documents. This process has changed from the historical perspective, but has retained its continuity. Today, there are difficulties with the dissemination of documentation that would correspond to the digital age in Ukraine for a number of reasons (lack of modern regulatory framework, qualified specialists, literature, funds, renewal of staff, loss of culture in working with documents). Critical consideration of the field of office work, the dynamics of its problems and ways to solve it in the historical perspective is an important condition for further development. That is why the purpose of the article is to identify and consider the main stages of the organization of documentation in Soviet Ukraine.

The state of documentation research in the Soviet times can be mainly regarded as a consideration of certain issues within the planned centralized issues, mainly by archivists. A lack of relevant research has been observed in other countries, too. Thus, the well-known researcher of document-based information processes David O. Stephens noted that when he first became interested in international documentation in the late 1980s, he found no available high-quality literature on this topic (Stephens, 2001).

Studies into Soviet Ukrainian documentation as an organic part of the sciences of documentation communication began to actively develop at the turn of the century. In the works of V. V. Bezdrabko, S. G. Kuleshova, I. O. Petrova, Y. I. Palekha, and V. T. Savitskyi, these issues are analyzed within the history of documentation science or in office work manuals. The studies by Zagoretska (2005), Salynikova (2013, pp. 153-158), Sokur (2015), Selychenkova (2004), and others are devoted to certain aspects of the present problem. An analysis of their scientific achievements suggests that the history of the organization of documentation has not yet formed into a clear system of knowledge and requires some rethinking, refinement of estimates, including periodization. Thus, 
I. N. Kuznetsov distinguishes between two stages in the evolution of Soviet office work-1917-1973: introduction of the Unified State System of Office Work, and 1973-1991: devising of the foundation of modern office work on the basis of new information technologies (Kuznetsov, 2015, pp. 28-33). L. A. Doronina writes about three periods: the restructuring system of organization in office work during the 1920s-1930s; the almost complete lack of development in the 1940s and 1950s; and creation of a significant legal framework, norms and rules of record keeping in the 1960s and 1990s (Doronina, 2018). Some authors omit the period of the 1940s-1950s. We consider it appropriate to distinguish between five periods, understanding that any periodization of social processes is conditional; some of them intersect or go beyond a particular stage. Stages are distinguished on the basis of dominant events that have influenced the social process, helping to structure the available historical material. The authors of the article suggest the following periodization-Stage I: the 1920s; Stage II: the 1930s; Stage III: 1940-1950; Stage IV: 1960-1973; and Stage V: 1973 - the 1980s.

In various stages of history, the sphere of documentation has been established by public administration bodies with different goals and priorities. Under the conditions related to the revival of the Ukrainian statehood (1917-1920), among the priority tasks were the translation of office procedures into the state language, creation of own effective system of office work for establishing communication between the center and the regions, preservation of documentation fund, etc. The Bolshevik coup aimed at radically breaking the old state apparatus and involving the working masses in it, which significantly changed the concept of management and the system of office work.

On January 6, 1919, Ukraine became known as the Ukrainian Socialist Soviet Republic (Ukrainian SSR). Legal registration of Soviet statehood took place on March 14, 1919, when the III All-Ukrainian Congress of Soviets of Workers', Peasants' and Red Army Deputies adopted the first Constitution of Ukrainian SSR (Konstytuciy i konstytuciyni akty..., 2011, pp. 56-61). The last stage of losing independence for Ukraine ended in 1922, when the First Congress of Soviets approved a declaration on the formation of the USSR and a union treaty. 


\section{The beginnings of the formation of documentation science in Ukraine}

The first stage in the evolution of Ukrainian documentation in the Soviet era is related to the 1920s. However, the first legislative act in the Ukrainian SSR on record keeping was the decree of the Council of People's Commissars (CPC). It established the state ownership of archival documents and the administrator to the documentation heritage- the People's Commissariat of the Ukrainian SSR as the Archival Section of the All-Ukrainian Committee for the Protection of Art and Antiquities. The task of the People's Commissariat was to study the theory and practice of record keeping and archiving (Kurylo, 2014, pp. 19-20). On the territory of the Ukrainian SSR and other republics, a single form of business document with mandatory details was enforced. It was established by the resolution of the Council of People's Commissars of the Russian Soviet Federative Socialist Republic (RSFSR) from 2 March 1918, 'About the configuration of forms for state institutions' ('Sobranie uzakoneniy...', 1942, p. 401), in which much attention was paid to the rationalization and simplification of office work. Thus, Ukrainian office work was translated into the norms of the Russian Federation.

In July 1919, relevant commissions were established in connection with the reorganization of the Archival Section into the Main Archival Department of the People's Commissariat of the Ukrainian SSR in the provincial departments of public education. The commissions were tasked to oversee the organization of office work and selection of valuable documentation. From March 1920, the work of provincial commissions was organized under the leadership of the Special All-Ukrainian Archival Commission, which had broad powers. The first legislative act on the nationalization and centralization of archival affairs was adopted on April 20, 1920 by the CPC of the Ukrainian SSR 'Provisional Regulations on Archival Affairs'. New tasks were assigned to the Main Archive Directorate under the Council of Ministers of the USSR (Glavarkhiv of the USSR) to control the conduct of current records in institutions in accordance with the Code of Laws on Public Education of the Ukrainian SSR, adopted on 25 October 1922 (Kodeks zakoniv..., 1922). Thus, the party-administrative control in office work gradually gained strength.

During creating the Soviet state apparatus, attention was paid to accelerating the processes of document treatment and processing of cases, reducing correspondence (through using telegraph, telephone), combating bureaucracy, 
and austerity (including consumables). Low-grade yellow paper, sometimes wrapping or cigarette paper, was used, and the ink was diluted. For several decades, these documents rapidly deteriorated, crumbled, faded ink, and lost text in the archives. Despite certain regulatory, organizational and methodological measures, the documentation process remained unsatisfactory. Replacement of the old bureaucracy with unskilled personnel of workers and soldiers and sabotage led to a decline in the level of documentation management. This caused an objective need to streamline the processes of "Soviet writing" through the dissemination of theoretical and practical knowledge of office work using achievements elsewhere in the world.

At that time, manuals began to be published. Here it is worth referring to the work 'Decimal system in administrative proceedings' (1921) by O. F. Evtikhiev. This system was initiated by P. Otle and the International Bibliographic Institute and used in some institutions in Belgium, Holland, and Spain. The preface, on behalf of the Commission for the Review of Institutions of the Ukrainian SSR, announced its intention to publish a review of administrative records in the leading European countries, the Code of Rules on Administrative Records, adopted by the World Congress of Administrative Sciences in Brussels (1910). It illustrates the efforts of the practical implementation related to advanced European scientific developments in Ukraine.

The creation of an effective office work system through the organization of research centers in the republics to solve regional theoretical and practical problems of documentation management activities was a factor in strengthening Soviet power. At this stage, the dominance of scientific approaches in the rationalization of management, scientific organization of labor (SOL), improving documentation, and perfecting record keeping in the management apparatus can be observed. Organizational and scientific activities in the field of management were fixed in regulations and the creation of public organizations network, institutes and laboratories that dealt with issues of SOL and reference activities. In 1922, the All-Ukrainian Institute of Labor (AUIL) at the Southern Bureau of the All-Ukrainian Central Executive Committee in Kharkiv was established to solve topical problems concerning the organization of office work on the basis of SOL. The activity range of the institute was wide: from conducting "field" research in enterprises to providing scientific and practical advice. The institute established extensive international relations and the results of its research were on the level of the corresponding institutions in Western Europe (Salynikova, 2013, p. 153). The issues of scientific research are clearly illustrated in the works of the 
Vira Gamaliia

Igor Dovzhuk

Halyna Sichkarenko

institute's staff and other documents stored in the Central State Archives of the Highest Authorities and Administration of Ukraine.

In 1926, the State Institute of Management Engineering (SIME) began to develop and implement new technologies in the field of office work. The SIME, according to its statute, dealt with the problems of management techniques, the creation of standard projects and methods of labor rationalization, and also conducted consulting and promotional work. One of the important areas of the institute's work was the training of innovators' movement (courses in labor and economics, retraining of the technical staff) and the relevant scientific and methodological support (Salynikova, 2013, p. 157).

Despite the fact that the issue of office work was not a priority at the institute, its achievements remain significant-it was the document flow of institutions and methods of its organization; paths of registration and rational ways related to accounting documents; control of execution and storage of records. The movement of the main document flows was studied using graphical methods, and the best options were proposed. In the SIME's project 'The new system of office work', the general principles for the optimization of the institutions' activity were laid out, among them the uniform organization of office work in an institution; registration of documents in a simplified form; reference work requiring less energy and time; control over the execution of documents on the merits, etc. (Gosudarstvennyi institut..., 1934).

The SIME's experience in the organization of office work was widely used by the All-Ukrainian Institute of Labor. However, the problem of creating an effective system of record keeping was not solved, which led to the reorganization of AUIL on July 30, 1929 into the Institute for Management Rationalization (IMR) at the People's Commissariat of Workers' and Peasants' Inspection (PC WPI) of the Ukrainian SSR. The institute had branches in Kyiv, Dnipropetrovsk, Odesa, and Stalino, even though their staff was small. The IMR became the legal successor of the AUIL. The regulation defined the institute as a research institution that develops issues of rationalization of management in accordance with the achievements of modern science and technology. The institute was to systematize the rationalization experience, to develop norms for unification and standardization of documentation (typologization of documents, accounting forms, uniform rules of record keeping, etc.). Schools of innovators (advanced training) worked at the IMR too. According to the resolution of the Secretariat of the Central Committee and the Presidium of the Central Election Commission PC WPI in September 7, 1931, a higher education institution was organized at the IMR—-the Higher 
School of Management Rationalization. Until the early 1930s, the IMR provided solutions of problems related to the rational construction of the administrative apparatus in Ukrainian SSR (Selychenkova, 2004, pp. 3-4).

The greatest achievement of that time was the development of 'Rules for the organization of the archival part of the records in state, professional and cooperative institutions and enterprises' (1928) (Osnovni tendenciyi..., 2020), which provided recommendations for lists of cases in institutions and rules for their destruction, as well as the SIME project 'The general rules of documentation and document circulation' (1931), which provided for the introduction of a single organization of office work for all union institutions (Salynikova, 2013, pp. 153158). The project summarized both the best practices and research of native and foreign scientists. It was the first attempt to create a comprehensive regulatory document that contained uniform rules of organization and technology of office work. 'The general rules' were not approved, in connection with the liquidation of the SIME in April 1932, the specialists of the institute were repressed.

Gradually, documentation became more orderly in structure, content, and form. Systems of special documentation were developed. The statistical authorities were instructed to streamline the forms of periodic reporting and bookkeeping, especially on planning, accounting and control. After the liquidation of the IMR (in 1934), the scientific and methodological support of documentation was transferred to the departmental level, which was handled by the archival service under the auspices of the People's Commissariat for Internal Affairs (NKVD) of the USSR. The country began to feel the lack of standardized office work, which complicated the functioning of a single management information space.

An important factor during this period was the policy of "Ukrainization" as a factor in consolidating Soviet power through the using national factors in the formation of the party-state apparatus. In 1925, the Ukrainian language was officially introduced into office work, and all officials were to use the Ukrainian language in government correspondence and publications. In 1927, Kaganovych announced that all party records would also be kept in Ukrainian. However, at the end of the famine of 1932, "Ukrainization" was officially condemned as "Petliurist". In January 1933, Secretary of the Central Committee of the Communist Party Postyshev began the struggle against "Ukrainian bourgeois nationalism", in the course of which a number of scientific institutions were liquidated. The almost ten-year period of "Ukrainization" was stopped. The practice of "Russification" and the system of Soviet office work was restored in state and public life. 
Vira Gamaliia

Igor Dovzhuk

Halyna Sichkarenko

It should be mentioned that the policy of "Polonization" was also pursued in Western Ukraine in the interwar years. Use of Ukrainian language in state institutions was prohibited, all terms related to Ukrainian affiliation (Western Ukraine, Ukrainian) were excluded. Mass personnel purges were carried out in state and county institutions, all Ukrainian intelligentsia and students were removed, and so on. In 1921, the League of Nations condemned the actions of the Polish government and recognized Poland as the de facto military occupier of Galicia. However, the repressive policy did not stop, which led to the radicalization of Ukrainians' protests.

Thus, during the first stage of the development of documentation in the 1920s, significant measures were taken to unify and standardize the circulation of documents. This was accompanied by the nationalization of the documents and archival fund, the formation of normative-methodical and scientific base, "Ukrainization", Soviet personnel policy, the emergence of a special documentation system: statistical, planning, accounting, personnel. Manuals, branch, normative and methodological materials were published, including instructions on record keeping, instructions, rules, and also research on standardization, and unification of special documentation systems. Preparation of the 'General rules of documentation and document management' can be considered a certain result of this fruitful activity. The period of the 1920s can be considered as the most favorable for the organization of research in the field of office work, but the work was carried out somewhat chaotically and the regulatory framework and the organization of office work in general were not fully settled.

\section{Further development of documentation science in the $1930 \mathrm{~s}$}

The second stage in the development of documentation is the 1930s, although researchers do not view it as separate, but consider it together with the processes of the 1920s. Meanwhile, these periods differ significantly. If the 1920s went down in history as a period of "Ukrainization", the 1930s became an era of "great upheaval" and terror, famine, and unification of all aspects of Ukrainian life. Records were translated into Russian, the management initiative was blocked, and all circulars received from above had to be blindly copied. The reorganization of the local authorities (district executive committees) led to structural changes in the organization of office processes. 
The Constitution of the USSR (1936) had a significant influence on the organization of documentation. All norms with minor changes were transferred to the Constitution of the Ukrainian SSR in 1937 (Kodeks zakoniv..., 1922, p. 81100). According to the Constitution, local councils and executive bodies were given the right to issue orders, which, on the one hand, intensified office work in the country, and on the other-led to increasing administrative documentation, weakening executive discipline and expanding the administration. Most directives and regulations did not contain clear instructions, but only duplicated the directives of higher authorities. In order to overcome the crisis in office work, the reorganization in the departments of regional committees, district committees and the Central Committee of the CPSU was started, but this did not bring significant changes (Stephens, 2001).

In 1938, the archival institutions of the republics were subordinated to the NKVD, which increased the secrecy of documentation. The main documents were the protocol, directive letter and circular. Minutes from the meetings of the bureau or secretariat of the party committee were marked "top secret." The actual merging of the party and state apparatuses gave rise to a ban on copying extracts and references to the minutes of the party committee. Strict control by party bodies led to the rewriting of their decisions, which provoked a lot of homogeneous documents that completely duplicated the All-Union counterparts.

A significant reduction in documentation research during this period does not mean that it stopped. Theoretical and applied activities continued in some large departments, where branch, normative and methodical materials were published: instructions on record keeping, directives, rules, etc. Research was conducted on standardization and unification of special documentation systems (accounting, personnel), rationalization of work with applications, complaints and letters of workers. However, the basic normative document on the settlement of office work was not created. There were separate instructions, directives, methodical directions, and individual manuals, the informative part of which was often not coordinated with one another.

The accumulation of documentation problems required a solution. In 1941, the First Intersectoral Meeting on Office Equipment convened to consider urgent issues: the creation of a coordination center on office work and regulatory framework, unification of office work, training and retraining, opening of the All-Union Research Institute to develop a set of problems in document science, etc. (Sokur, 2015). The implementation of the issues was disrupted by the war. 
Thus, during the 1930s, a rigid administrative-command system of government was established, which finally destroyed the research centers engaged in the organization of office work. However, the system of Soviet citizens' registration was developed. During the reorganization, all office work and archival institutions in the USSR were completely unified and deprived of national specificity. Attempts to settle certain components of record-keeping processes were sporadic. No basic normative document has been created. Scientific developments of the 1920s and 1930s in the field of office work were not used in practice, as they were incompatible with the command-administrative system.

\section{Functioning specifics of office work in the 1940-1950s}

In the works of researchers, this period is sometimes not distinguished at all, or is characterized as a time of almost complete absence of developments in the field of office work (Doronina, 2018). However, this is not entirely true.

In the 1940s, the methodological guidance and control over the organization of office work was centralized to the Main Archival Department (Glavarkhiv), the purpose of which was to fully replenish the archives with appropriate sets of documentation. Therefore, the work was carried out mainly on the standardization and unification of special document systems (organizational and administrative, accounting, personnel).

With the beginning of the war, the evacuation of the documentary part of office work from the Ukrainian SSR to the eastern regions of the USSR became a priority task. Secret funds, which were important for the NKVD, defense capabilities, especially valuable documents, and scientific reference apparatus, were subject to immediate export. During 1941-1943, the main office was located in Zlatoust. Often the operational tasks in the evacuation were the processing of documents to identify counter-revolutionary elements. Scientific and methodological research slowed down, but did not stop. In order to establish current record keeping and timely transfer of cases for storage in February 1943, 'Temporary instructions on record keeping, the procedure for registration, storage and archiving of completed cases in Soviet enterprises and institutions' was issued. That same year, the Glavarkhiv made another attempt to create uniform rules for working with official documents. A draft 'Instructions for the production of the documentary part and protection of documented materials 
in contemporary records of institutions, organizations and enterprises of the USSR' was developed. It recognized the necessity of uniform requirements for documents and attempted to unify them (Sokur, 2015). However, the project was not approved. The same year, the first list of standard management documents was issued, which established the terms of their storage. This list became the basis for the examination of documents' value in office work.

In occupied Ukraine at the end of 1942, the National Administration of Archives, Libraries and Museums under the Reich Commissar of Ukraine was established. It took control of Ukrainian archival institutions and office processes on the German model, and the next year the mass export of valuable documents to Nazi Germany began.

Soviet record keeping was resumed in liberated Ukraine. There was an intensification of clerical processes and increasing attention to them from the state. In 1944, the 'Instruction on the production of documentary part and protection of documentary materials of current office work in ministries and other institutions, organizations and enterprises of the Ukrainian SSR' was approved. They prescribed organizational forms of office work, stages of document circulation and the main types of documents. Some institutions had to develop their own instructions on record keeping and lists of documents (Sokur, 2015).

In the republican institutions more and more attention was paid to the organization of office work, the formation of cases according to the nomenclature coordination with the archival institutions. In 1944, the Department of Archival Studies was opened at the Kyiv State University. It trained specialists in the field of archiving and record keeping. There was awareness at the state level that a properly organized current record-keeping process is the key to successful management. It intensified the legal and methodological support for the activities of authorities at all levels. On January 17, 1948, the Resolution of the Council of Ministers (CM) of the USSR 'On streamlining office work in village councils of workers' deputies' was adopted. According to it the following documents: 'Instruction on record keeping in the Village Councils of Workers' Deputies of the Ukrainian SSR' (July 5, 1949) and 'On approval of the Instruction on record keeping in the executive committees of the district Soviets of Workers' Deputies of the Ukrainian SSR' (October 20, 1950) were issued. According these documents, Ukrainian was determined as the language of office work institutions (Sokur, 2015). 
It should be mentioned that the main focus during this period was on improving the administrative activities of Soviet institutions (as Khrushchev's struggle for power was taking place). Thus, the resolution of the Central Committee of the CPSU of January 25, 1954 'On serious shortcomings in the work of the party and state apparatus' pointed to harmful bureaucratic practices, when the main attention of the personnel was focused at drafting numerous directives, resolutions, certificates, letters and reports. As a result, national and departmental statistical reporting was reduced almost three times, periodical accounting of enterprises - two times, and collective farms - five times (Istoriya deloproizvodstva ..., 1974, p. 124).

This way, despite the difficult years after the war, the period of 1940-1950s on a national scale was marked by the implementation of numerous arrangements to increase the level of office work in public institutions, attempts to rationalize and unify it. A number of acts were issued on the procedure for documenting management activities and in the field of special (sectoral) systems. Archival organizations were given extensive authority in the organization of office work. The leadership of the republic began to pay more attention to the improvement of office work, which gave positive practical results.

\section{Intensification of documentary activity in the 1960 s-1973}

The fourth period of the development of documentation - from the 1960s to 1973 - is associated with the "explosion of documentary activity in the society" and the rapid development of information science, which contributed to a new view towards documentation. It became to be considered as the only information system that promotes the achievement of management goals. In 1960, the AllUnion Meeting on Labor Mechanization of Engineering and Technical Workers and Employees and Administrative Staff was held in Moscow. Its decisions largely coincided with the recommendations of the 1941 meeting: the urgency of creating a specialized institute to develop unified state system of record keeping (USSRK), and the necessity for research in the field of SOL. A characteristic feature of the 1960s was the strengthening of responsibility for the organization of office work in enterprises and organizations by archival institutions. They were responsible for the regulatory and scientific-methodological support of this activity. According to the Regulations (1961), the Archival Department of the Ukrainian SSR was given the right to control the documentary part of 
office work in enterprises and institutions. Comprehensive inspections were introduced into practice; ministries and departments were assisted in compiling the nomenclature of cases, meetings, and consultations. Courses on office work were organized for representatives of district executive committees, village councils, and collective farms. According to the CM Resolution of Ukrainian SSR 'On measures to improve archival affairs', issued on September 27, 1963, the archives of the republic were tasked with organizing the training of employees for office services, which were implemented on permanent three-month courses at Kyiv State University.

In 1966, the All-Russian Research Institute of Documentation and Archival Affairs (ARRIDAA) was established on the basis of the Central Research Laboratory of the USSR State Archives to perform tasks related to improving the level of record keeping and development of the USSRK (VNIIDAD..., 2020). It was brought about by the interest of the government to solve problems through economic reforms in the country. The result of the institute's activity was the inclusion of documentation science as a discipline into the nomenclature of scientific specialties in 1970. It was the beginning of the training of qualified clerks. Further attempts to improve the regulatory and scientific-methodological framework of office work in the USSR were associated with the development and implementation of USSRK. Its main provisions were a scientifically organized set of rules, regulations and recommendations for the organization of office processes, the functioning structure of office services, economics and organization of the office staff work, mechanization of office work, etc.

The main developer of the USSRK was the ARRIDAA, but a wide range of departments and organizations were involved in this work, as well as national institutions, in particular, Ukrainian ones. Thus, the Glavarkhiv of the USSR obliged the Archival Department of the Ukrainian SSR to take measures for the formation of managing staff and archival institutions with qualified specialists in the field of documentation science, to consider the possibility of creating special units, creative groups for research and developing unification of organizational and administrative documentation, involving scientific institutions, ministries and departments of the republic to perform these tasks. The Chief Archivist of the USSR regularly sent to the Archives Department of the republic for consideration draft documents prepared by specialists of the USSR Chief Archives and the ARRIDAA staff (including materials provided by the Archives Department of Ukrainian SSR), with a request to present their comments and suggestions. In 1971, the Archives Department of the Ukrainian SSR, on behalf 
of the Department of Affairs of the Republic of Ukraine, conducted a study of the USSRK project and prepared a meaningful review with comments for the ARRIDAA.

In 1973, a resolution of the State Committee for Science and Technology under the CM of the USSR was approved by the USSRK, who recommended it to ministries and departments for use. The USSRK led to large-scale development and further implementation of unified documentation systems, a unified system of classification and coding of technical and economic information, in particular in terms of their using in automated control systems (ACS). At the same time, a series of all-Union standards were prepared and approved. Thus, in the process of compiling and processing documents according to the USSRK should have complied with the provisions of GOST 6.38-72 'The system of organizational and administrative documentation. Basic provisions.' (GOST 6.38-72.., 1972). The form of the document and placement of details had to correspond to GOST 6.39-72 'The system of organizational and administrative documentation. Sample form.' (GOST 6.39-72..., 1972).

In the 1960s, the Ukrainian branch of the Research Institute of Planning and Standards under the USSR State Planning Committee operated in Kyiv. It was a scientific institution where the study of office work organization was no longer carried out on the basis of archival principles, but based mainly on managerial, economic aspects. Some assistance in the development and explanation of normative and scientific-methodical support of the organization of office work, generalization of experience, control over the state of office work, and introduction of its progressive forms was given by The Scientific and Information Bulletin of the Archival Department of the Ukrainian SSR. It has been published since 1965 under the title Archives of Ukraine, with meaningful articles in the section 'Record keeping'.

Thus, the development of documentation since the 1960s is associated with the transfer of authority to archival institutions for organizing and controlling record keeping, and participation in regulatory and scientific-methodological support. Adoption of the USSRK has led to large-scale development and implementation of unified documentation systems, a single system of classification and coding of information, in particular in terms of their use in automated control systems. 


\section{Information science and office work in 1973-the 1980 s}

In the period from 1973 to the end of the 1980s, the formation of modern office work was performed on the basis of the using new information technologies. The development of all-Union classifiers of technical and economic information-the All-Russian Classifier of Management Documentation (OKUD), the All-Russian Classifier of Enterprises and Organizations (OKPO), the All-Union Classifier of National Economy Branches $(\mathrm{OKONH})$ and the Unified Documentation Systems (UDS) - was continued. Introduction of these documents has significantly improved the design of documentation, simplified the procedure for searching, accounting and storage of documents and documentation information, and created a basis for automation of document management. The implementation of the USSRK provisions, standards and classifiers has helped to increase the level of record keeping, optimize the structure and manage staff. But new technologies for working with documents (personal computers) were not taken fully into account. This shortcoming was eliminated during the revision of the USSRK and the publication in 1988 of its new edition-the State System of Documentation Management (SSDM) (Gosudarstvennaya sistema..., 1988). Record keeping was given a new name-documentary support of management (DSM).

Issues concerning the implementation of the latest developments in the field of office work were assigned to the organizational and methodical committee on office work of the republic, established in April 1985, which operated under the Main Archival Department of the Ukrainian SSR. Meetings and seminars, advanced training courses for managers and specialists of the republic in the specialty 'Record Keeping and Archival Affairs' were held on the basis of the committee.

In the 1980s, the normative and methodological basis for storing documents in office work and archives was revised. In 1989, a 'List of standard documents formed in the activities of state committees, ministries, departments, agencies, organizations and enterprises, indicating the retention period' was published, which also became a practical guide for each clerical service in organizing the storage of documents. During this period, time standards were developed for clerical operations. On the basis of the established formulas of labor costs, the quantitative structure of employees of clerical service was calculated. At the end of the 1980s, a holistic system of documentation management was devised, which met the standards of drawing up official documents. Material, technical 
and organizational support of office work was improved, the normative and scientific-methodological basis of the republic was formed, popular science publications on organization and working with documents in the Ukrainian SSR were introduced into practice, the training and retraining of personnel was started, and relevant educational and reference literature began to be published.

Thus, from 1973 to the end of the 1980s, a significant legal framework was developed in the field of record keeping, a system of documentation standards, classifiers, and unified documentation systems were created. CM of the Ukrainian SSR approved the Model Instruction on Record Keeping for Institutions and Organizations of the Ukrainian SSR. In 1988, the State Management Documentation System was established. At the same time, GOST introduced the technology of centralized control over the composition of the created documents through their inclusion in the tables of forms, approved by the head of the organization, but its practical application did not become widespread at the time. The long-term plan for 1976-1990 provided for the establishing a branch of the All-Russian Research Institute of Documentation and Archival Affairs in Kyiv.

Soviet Ukraine faced important tasks in the field of documentation: from carrying out certain governmental measures concerning streamline documentation to the introduction of the USSRK and office work based on new information technologies. In the 1980s, negative trends in the organization of office work in the Ukrainian SSR became noticeable-the lack of relevant research centers, lagging behind the Western countries in the use of information technology, training problems, the introduction of SSDM and others. At the same time, the republic formed a holistic system of documentation management that met the standards, improved its logistics and organizational support, formed its own regulatory and scientific-methodological base; there was extensive training and retraining, and educational literature was published. It became the basis for the formation of documentation in independent Ukraine by means of using new information technologies. 


\section{Conclusion}

To sum it all up, the organization of documentation in Soviet Ukraine, as mentioned above, passed through five stages. The stages, on the one hand, coincide with the periods of transformation of the USSR, but on the other hand, they follow a certain logical course of development. Periodization of this activity was influenced by both the change in types of power, the struggle within the party-state apparatus, and the requirements of the scientific and technological progress, the theoretical understanding of processes. Ukraine was influenced by the policy of the central authority in the field of management and organization of office work, but also in some way influenced the formation of this policy. The Ukrainian SSR was an active participant in the introduction of scientific methods and information technologies in the field of documentation and the creation of a nationwide system of record keeping.

\section{References}

Bondarenko, Z. V. (1978), 'Pro vprovadzhennya YeDSD u ministerstvakh i vidomstvakh URSR' [About the introduction of USSOW in the ministries and departments of the Ukrainian SSR], Arkhivy Ukrayiny [Archives of Ukraine], no. 1, pp. 43-49.

Derzhavna arkhivna sluzhba... (2020), Derzhavna arkhivna sluzhba Ukrayiny. Ghenezys [State Archival Service of Ukraine. Genesis]. Retrieved from https://archives.gov.ua/ en/history-and-tasks/ [accessed Sep 2021]

Doronina, L. A. (2018), 'Organizaciya i tekhnologiya dokumentatsionnogo obespecheniya upravleniya' [Organization and technology of documentation support for management]. Retrieved from https://studme.org/1529052722605/ dokumentovedenie/deloproizvodstvo_sssr [accessed Sep 2021]

DSTU 8344:2015... (2015), DSTU 8344:2015 Informaciya ta dokumentaciya. Vydannya.

Osnovni elementy. Terminy ta vyznachennya ponyaty [DSTU 8344:2015 National Standards of Ukraine. Information and documentation. Edition. The main elements. Terms and definitions], Kyiv: UkrNDNC.

GOST 6.38-72... (1972), GOST 6.38-72 Sistema organizacionno-rasporyaditel'noy dokumentacii. Osnovnye polozheniya [GOST 6.38-72 The system of organizational and administrative documentation. Key points]. Retrieved from https://files. stroyinf.ru/Index2/1/4294719/4294719440.htm [accessed Sep 2021]

GOST 6.39-72... (1972), GOST 6.39-72 Sistema organizacionno-rasporyaditel'noy dokumentacii. Formulyar-obrazec [GOST 6.39-72 The system of organizational and 
Vira Gamaliia

Igor Dovzhuk

Halyna Sichkarenko

administrative documentation. Sample form]. Retrieved from http://www.normacs. ru/Doclist/doc/44UF.html [accessed Sep 2021]

Gosudarstvennaya sistema... (1988), Gosudarstvennaya sistema dokumentacionnogo obespecheniya upravleniya (GSDOU): Prikaz Glavarhiva SSSR ot 25 maya $1988 \mathrm{~g}$. № 33 [The state system of documentation management (SSDM): Order of the Main Archive of USSR of 25th of May 1988, no. 33]. Retrieved from http://docs.cntd.ru/ document/901730479 [accessed Sep 2021]

Gosudarstvennyy institut... (1934), Gosudarstvennyy institut tehniki upravleniya (ITU) Narodnogo komissariata Raboche-Krest'yanskoy inspekcii. 1926-1932. Putevoditeli po rossiyskim arhivam [The State Institute of Management Technology (IMT) of the People's Commissariat of the Workers and Peasants Inspection. 1926-1932. Guides to Russian archives]. Retrieved from http:/guides.rusarchives.ru/funds/6/ gosudarstvennyy-institut-tehniki-upravleniya-itu-narodnogo-komissariata-rabochekrestyanskoy [accessed Sep 2021]

Istoriya deloproizvodstva... (1974), Istoriya deloproizvodstva v SSSR. Uchebnoe posobie [The history of office work in the USSR. Tutorial], Moscow: MGIAI.

Kodeks zakoniv... (1922), Kodeks zakoniv pro narodnu osvitu USRR: pryynyato 25.10.1922 r. tretyoyu sesiyeyu VUCVK [Code of Laws on Public Education of the Ukrainian SSR: adopted on October 25, 1922 by the third session of the All-Ukrainian Central Executive Committee]. Retrieved from https://leksika.com.ua/19930625/legal/ kodeks_zakoniv_pro_narodnu_osvitu_usrr_1922 [accessed Sep 2021]

Konstytuciyi i konstytuciyni akty... (2011), Konstytuciyi i konstytuciyni akty Ukrayiny. Istoriya i suchasnisty. 3-e vyd. (Do 15-richchya Konstytuciyi Ukrayiny i 20-yi richnyci nezalezhnosti Ukrayiny) [Constitutions and constitutional acts of Ukraine. History and modernity, 3rd ed. (To the 15th anniversary of the Constitution of Ukraine and the 20th anniversary of Ukraine's independence)], Kyiv: Yurydychna dumka.

Kurylo, T. V. (2014), Pravova okhorona kulturnoyi spadshhyny Ukrayiny. Monoghrafiya [Legal protection of cultural heritage of Ukraine. Monograph], Lviv: Lvivsykyi yurydychnyi instytut MVS Ukrayiny, "Novyy svit - 2000".

Kuznetsov, I. N. (2015), Dokumentatsionnoe obespechenie upravleniya personalom: uchebnik i praktikum dlya prikladnogo bakalavriata [Documentation support for personnel management: textbook and workshop for applied bachelor's degree], Moscow: Yurayt.

Matyash, I. B. (2001), 'Osoba v ukrayinsykiy arkhivistyci: Bioghrafichni narysy' [Person in Ukrainian archival science: Biographical essays], Derzhavnyi komitet arkhiviv Ukrayiny [State Committee of Archives of Ukraine], Kyiv.

Mayakovska, N. V. (2013), 'Centralynyy derzhavnyy arkhiv vyshhykh orghaniv vlady ta upravlinnya Ukrayiny' [Central State Archive of the Highest Authorities and Administration of Ukraine], Encyklopediya istoriyi Ukrayiny [Encyclopedia of History of Ukraine], vol. 10, Kyiv: Naukova dumka. 
Myronenko, O. M. \& Ksenko, I. B. (2008), 'Konstytuciya SRSR 1936' [Constitution of the USSR 1936], Encyklopediya istoriyi Ukrayiny [Encyclopedia of History of Ukraine], vol. 5, Kyiv: Naukova dumka.

Mihaylichenko, D. Yu. (2012), 'Vseukrainskiy institut truda i stanovlenie har'kovskoy shkoly nauchnogo menedzhmenta (1921-1930 gg.)' [All-Ukrainian Institute of Labor and the establishment of the Kharkiv School of Scientific Management (1921-1930)], Gileya: naukoviy visnik. Zbirnik naukovih prac [Gilea: scientific bulletin. Collection of scientific works], Kyiv: VIR UAN, vol. 60, no. 5, pp. 100-106.

Orghanizaciya dilovodstva... (2020), Orghanizaciya dilovodstva v 1917-1941 rr. [Organization of office work in 1917-1941]. Retrieved from https://stud.com. ua/42338/dokumentoznavstvo/organizatsiya_dilovodstva_1917_1941 [accessed Sep 2021]

Osnovni tendenciyi... (2020), Osnovni tendenciyi rozvytku kultury dilovodstva v USRRURSR [The main trends in the development of office culture in Ukrainian SSR]. Retrieved from https://studfile.net/preview/7168499/page:5/ [accessed Sep 2021]

Salynikova, N. V. (2010), 'Peredumovy stvorennya Instytutu racionalizaciyi upravlinnya' [Prerequisites for the establishment of the Institute for Management Rationalization]. Socyalynaya rabota. Socyologhyya: VI Mezhdunar. nauchno-prakt. konf. "Unyversytetskaya nauka - 2010» (Maryupol, 19-21 maya 2010 gh.): sb. statey [VI International scientific and practical conference "University Science - 2010" (Mariupol, May 19-21, 2010): Collection of articles], Maryupol, pp. 307-310.

Salynikova, N. V. (2013), 'Naukova diialnist u sferi dilovodstva Vseukrainskoho instytutu ratsionalizatsii upravlinnia' [Scientific activity in the field of office work in the All-Ukrainian Institute of Management Rationalization], Istorychni i politolohichni doslidzhennia [Historical and political science research], vol. 3, no. 53.

Selychenkova, S. Z. (2004), 'Z istoriyi ekspertyzy cinnosti dokumentiv ta ukladannya perelikiv dokumentiv v Ukrayini u 1920-1930-ti roky' [From the history of examination of the value of documents and compiling lists of documents in Ukraine in 1920-1930], Studiyi z arkhivnoyi spravy ta dokumentoznavstva [Studies in archival affairs and documentation science], Kyiv, vol. 12. Retrieved from https://old. archives.gov.ua/Publicat/Studii/Studii_2004.12_02.php [accessed Sep 2021]

'Sobranie uzakoneniy...' (1942), 'Sobranie uzakoneniy i rasporyazheniy pravitel'stva za 1917-1918 gg.' [Collection of legalizations and orders of the government for 1917-1918], Upravlenie delami Sovnarkoma SSSR [Management of affairs of the Council of People's Commissars of the USSR], Moscow.

Sokur, L. A. (2015), 'Orhanizatsiia protsesiv dilovodstva v URSR: osnovni rysy y napriamy derzhavnoi polityky (1930-1950-ti rr.)' [Organization of office work processes in the USSR: the main features and directions of public policy (19301950s)], Naukovi zapysky Vinnytskoho derzhavnoho pedahohichnoho universytetu imeni Mykhaila Kotsiubynskoho. Seriia: Istoriia [Scientific papers of the Vinnytsia Mykhailo Kotsiubynskyi State Pedagogical University. Series: History], no. 23, pp. 91-96. 
Stephens, D. O. (2001), 'Megatrends in international records management. (International) Citation metadata,' Information Management Journal, vol. 35, no. 4. VNIIDAD... (2020), VNIIDAD Vserossiyskiy nauchno-issledovatel'skiy institut dokumentovedeniya i arhivnogo dela [All-Russian Scientific and Research Institute for Records and Archives Management (VNIIDAD)]. Retrieved from http://www. vniidad.ru/index.php?option=com_content \&view=article\&id=1153\&Itemid=779 [accessed Sep 2021]

Volkovynsykyy, V. M. \& Vasylyyev, V. Yu. (2011), 'Postyshev Pavlo Petrovych,' Encyklopediya istoriyi Ukrayiny [Encyclopedia of History of Ukraine], vol. 8, Kyiv: Naukova dumka.

Zahoretska, O. M. (2005), Normatyvne ta naukovo-metodychne zabezpechennia orhanizatsii dilovodstva $v$ Ukraini $u$ druhii polovyni XX - na pochatku XXI st.: Avtoref. dys... kand. ist. nauk [Normative and scientific-methodological support of the organization of office work in Ukraine from the second half of the 20th to the beginning of the 21st century: Extended abstract of the candidate's thesis], Kyiv.

Professor Vira Gamaliia, doctor of historical sciences, is head of the Department of Philosophy and History of Science and Technology at Kyiv State University of Infrastructure and Technology, Ukraine. She graduated from Kyiv State University and obtained the doctoral degree in the National Academy of Sciences of Ukraine, Dobrov Research Institute on Scientific and Technological Potential and Science History. For ten years she was also a lecturer at the National University of Kyiv-Mohyla Academy. Her scientific activity concerns the history of science and technology, gender problems, history of medicine, terminology.

Professor Igor Dovzhuk, doctor of historical sciences, graduated from Voroshilovgrad State Pedagogical Institute (in history) and East Ukrainian National University (in jurisprudence). For 15 years he headed the Department of Archival Studies of the East Ukrainian National University and a branch of the Department of History of Ukraine of the 19th to early 20th centuries at the Institute of History of Ukraine, NAS of Ukraine. Since 2016, he has been working as a professor in the Department of Documentation at the University in Pereyaslav. His research interests are the history and culture of Ukraine of the 19th-2oth centuries, and contemporary issues in archival science and Ukrainian law.

Professor Halyna Sichkarenko, Dr. Hab. in history, graduated with honours from the Faculty of History of St. Petersburg State University and defended her dissertation there. She received her doctorate from the Drahomanov's 
National Pedagogical University in Kyiv. For more than 35 years she has taught a number of courses in social sciences at Kyiv National Linguistic University. He currently works as a professor at the State University of Telecommunications and the Drahomanov's National Pedagogical University. Her research interests include the history of higher education of the 2oth21st centuries, current problems of documentation science. 